Article

\title{
Gender, Language and a Lipstick: Creating Cultural Change in a World of Paradoxes
}

\author{
Angeliki Alvanoudi 1,2 (iD \\ 1 Institute of Modern Greek Studies, Aristotle University of Thessaloniki, Thessaloniki 541 24, Greece; \\ aalvanoudi@ece.auth.gr \\ 2 Language and Culture Research Centre, James Cook University, Cairns, QLD 4870, Australia; \\ Angeliki.Alvanoudi@jcu.edu.au
}

Received: 30 June 2018; Accepted: 24 August 2018; Published: 27 August 2018

\begin{abstract}
This paper addresses the paradoxes and possibilities for academic feminism in the Third Millennium drawing on feminist linguistics. It targets the role of language in the construction of social gender, focusing on data from Greek, and shows that gendering discourse can effect cultural change. It is suggested that academic feminists can be agents of cultural change when they promote feminist language reform in the service of challenging the dominant gender order.
\end{abstract}

Keywords: social gender; grammatical gender; language reform; culture; cognition

\section{Introduction}

Third Millennium feminist scholars find themselves in a world of paradoxes and possibilities. This world is governed by old monsters, such as heteronormativity, racism and white male domination, and new gods, such as neo-conservatism, anti-intellectualism and pessimism. It is argued that feminism can fuel the engine of sociocultural transformations and give rise to alternative ways of thinking and living. The argument in the paper is structured as follows. First, three key paradoxes operative today are described: (i) the double bind of present-day academia as a corporate institution and a site for critical knowledge production, (ii) the free flow of knowledge in info-capitalism vs. the neoliberal anti-intellectual turn that demonizes nondiscriminatory or so called 'politically correct' language (henceforth PC language), and (iii) the power and limits of naming/labeling practices in the \#metoo movement. Second, these paradoxes are addressed from a feminist perspective. More specifically, the paper targets the role of naming/labeling practices drawing on language and gender research and shows that gendering discourse can effect cultural change. It is proposed that academic feminists can be agents of cultural change when they re-appropriate the notion of PC language in the service of challenging patriarchy and becoming women. This paper is an 'exercise' in breaking through paradoxes: it navigates the Third Millennium social landscape and seeks to identify ways for dismantling old monsters and displacing new gods with undutiful daughters.

\section{Paradoxes in the Third Millennium: Old Monsters and New Gods}

In the Prologue of Metamorphoses Braidotti $(2002$, p. 2) argues that the point for feminists is not to know who we are but what we want to become. In order to provide new figurations, that is, "materialistic mappings of situated, or embedded and embodied, positions", we need to create cartographies that account for our locations "in terms both of space (geo-political or ecological dimension) and time (historical and genealogical dimension)," and provide alternative representations for these locations "in terms of power as restrictive (potestas) and also as empowering or affirmative (potentia)" (Braidotti 2002, p. 2). In line with Braidotti's argument, this paper raises the following questions: Where do feminists find themselves in the Third Millennium? What is the context in which 
our identities take place? What are our socio-economic and symbolic locations? What are the possible sites and strategies for resistance? Feminists in western postmodern capitalist societies find themselves in a web of paradoxes, addressed below.

Paradox 1: the double bind of present-day academia as corporate institution and site for critical knowledge production. In the Third Millennium, capitalism has shifted into a type of cognitive info-capitalism in which 'immaterial' intellectual labor (Hardt and Negri 2003, p. 10) is the new source of surplus value. This means that most aspects of human social life and activities, including thought, imagination, creativity, emotions, and communication, are subjected to capitalist exploitation. That is, anything can be converted into a commodity that makes profit (cf. Negri 1989, p. 79) including knowledge produced by intellectual labor in corporate universities. This knowledge is a commodity shaped by the market and purchased by customers (students) at high or low prices (fees) (Alvanoudi 2009). The scientific 'precariat' working in corporate universities, that is, teachers and researchers, is exposed to 'toxic' academic cultures (Gill 2010) that generate intense workloads and make the articulation of activism and academic work difficult (Pereira 2016). Moreover, universities sustain power structures, such as "exclusionary systems of access, Eurocentric canons and curricular structures, sexist and racist campus cultures and the simultaneous marginalization and cooptation of feminist, race and ethnic, and gay/lesbian/queer studies agenda in the service of the corporate academy" (Mohanty 2003, p. 174). Yet, in spite of its toxic nature, academia remains a prominent site "of struggle and contestation" and "a crucial locus of feminist engagement" (Mohanty 2003, p. 175).

Paradox 2: the (free) flow of knowledge in info-capitalism vs. the neoliberal anti-intellectual turn that demonizes nondiscriminatory language. Third Millennium young workers are highly educated, 'connected'/networked individuals (Mason 2015) who have access to unlimited information via smartphones, tablets and laptops anywhere in the world, and participate in 'cultural industries' and 'knowledge-based' economies (Fairclough 2003, p. 19). Yet, in spite of technological advances and scientific progress, neoliberal right-wing movements adopt an anti-Enlightenment stance, which boils down to rejection of science and radical thinking, prejudice, sexism and racism. President Trump is an advocate of this anti-intellectual movement, when he expresses his mistrust against experts (e.g., denial of climate change) and targets PC language via his systematic political incorrectness. In making public statements about Mexico sending immigrants to the US who bring drugs, crime and they are rapists (Washington Post Staff 2015, n.p.), Trump legitimizes racism in discourse and he also inaugurates a new type of extreme right, white, male, neoliberal rhetoric that fuels public debates in the US and worldwide. The disregard of anti-sexist and anti-racist language is another way of colonizing public discourse and exercising power in terms of gender, race and class. Words matter. This brings us to the third paradox.

Paradox 3: the power and limits of labeling practices in the \#metoo movement. Trump's election and the reports of Weinstein's sexual predation have brought a revival of interest in feminism, as shown by women's massive marches on 21 January 2017, and the 2017 \#metoo digital movement. The origin of the \#metoo movement is traced back to 2006, when Tarana Burke, an African-American civil rights activist, started using the phrase $\mathrm{Me}$ too to raise awareness of sexual abuse and assault in society and make survivors visible. The phrase developed into a hashtag following Weinstein's sexual abuse allegations. A few months later the following paradox emerged: Handy Candy Makeup applied to trademark Me too for fragrances and makeup. The neoliberal market was about to incorporate radical difference into the profit-making enterprise. In postmodern capitalism which views language as commodity, a phrase that serves as a tool of feminist struggle can be transformed into a tool of women's covert oppression.

This paper addresses the ways in which we feminists can rethink and reinvent ourselves in a world of paradoxes. One can view paradoxes either as sources of depression and fear that lead to pessimism and 'no way out/no alternative' ideologies or as historical situations that expose new power relations and create possibilities for becoming new social subjects and building new narratives and alliances. In order to create a "room of our own" (Woolf 2002), we need to look into our "feminist 
survival toolkit" (Ahmed 2017, p. 235). What are the conceptual tools and practices that will help us dismantle patriarchy, subvert regimes of power and subordination and redesign our 'feminine' condition (Braidotti 1991)? My disciplinary location is linguistics. Therefore, my survival toolkit includes language, among other things. The paper follows a non-linear discussion of the three paradoxes presented above. In Section 3 I reconsider 'old debates' in feminist linguistics about the role of language in the maintenance of sexism drawing my examples from Greek, that is, a less-discussed language in the English-centered literature on gender. The discussion targets the interface between language, gender and cognition in talk-in-interaction and addresses issues related to paradoxes 2 and 3. In Section 4 I raise the issue of agency in implementing feminist language reforms. This brings us to academic feminism and paradox 1 .

\section{Gendering Discourse: Words and Why They Matter}

In the Third Millennium 'wars of words' (Cameron 2005, p. 118) are high on the agenda of mainstream politics generating paradoxes and challenges for feminists. In this section I discuss the role of gender linguistic structures in maintaining and reproducing the dominant gender order and I argue that language reform is a site of struggle and resistance for academic feminists that can effect cultural change. What follows is an attempt to create links between my prior work on language and gender and feminist politics.

In the postmodern era of cognitive capitalism, politics is defined by a 'language turn' (Fairclough 2003). Language is a semiotic tool that we use to navigate the social landscape and perform culture, that is, encode knowledge and values, maintain habits of behavior, sustain our symbolic and artifactual environments and make sense of what is happening in social interaction (Enfield 2013, p. 131). Therefore, language is central in social life. Knowing a particular language includes knowledge of grammar as well as knowledge of the social and cultural rules of using this grammar (Hymes 1964). If language has been important from the outset, what makes it particularly prominent in current political agendas (Paradoxes 2 and 3)? As Fairclough (2003, p. 19) insightfully points out, "the 'cultural turn' and the 'language turn' are first of all 'turns' in social life itself, and only secondarily turns in philosophy and social theory." 'Informational' or 'knowledge-based' and 'knowledge-driven' economies make culture and discourse significant in economic production and consumption (Fairclough 2003) and invite people to reconsider verbal hygiene (Cameron 2005) and the role of language as a political strategy to accomplish social and political change.

\subsection{Language and Gender: 'Doing' Culture}

Languages genderize discourse via grammatical and lexical gender, that is, linguistic items grammatically or lexically marked for female or male sex. The grammatical category of gender is a type of classifier systems, which categorizes nouns and nominals, and is found in many languages of the world (Aikhenvald 2000, pp. 77-80). In Greek and other Indo-European languages with two or three class systems, gender assignment in nouns with human reference is sex-based. ${ }^{1}$ In general, nouns denoting female humans are grammatically feminine, while nouns denoting male humans are grammatically masculine. Thus, there is a match between grammatical gender and referent's sex (cf. Hellinger and Bussmann 2001-2003). In Greek, grammatical gender is distinguished in nouns, articles, pronouns, adjectives, participles and demonstratives. These linguistic items codify referent's sex grammatically, as shown in (1) and (2):

(1) ablitís athlet(M).NOM.SG 'male athlet'

\section{älitria}

athlet(F).NOM.SG

'female athlet'

1 Although gender assignment in nouns with human reference is clearly semantically motivated, gender assignment in nouns with inanimate reference is semantically arbitrary. 
(2)
ikanós
ikaní
skilled.M.NOM.SG
'skilled'
skilled.F.NOM.SG
'skilled'

The gender of the noun controls agreement with other elements in the noun phrase or the predicate. In the noun phrases in (3) and (4) the gender of the head noun controls agreement with the article and the adjective:

(3) $o$

DEF.M.NOM.SG skilled.M.NOM.SG

aelitís

'the skilled male athlet'

(4) $i$

ikaní

älitria

DEF.F.NOM.SG skilled.F.NOM.SG

athlet(F).NOM.SG

'the skilled female athlet'

Moreover, referent's sex can be codified lexically. The lexical marking of nouns as female or male-specific is known as lexical gender. For example, the English nouns woman and man and the Greek nouns Jinéka 'woman' and ándras 'man' encode lexically the semantic property of femaleness and maleness respectively. Linguistic items that codify referent's sex grammatically or lexically index referent's gender referentially and directly (Ochs 1992). They ascribe female or male sex to the referent and, thus, categorize the referent as woman or man on the basis of a binary gender order. The use of referential indexes of gender communicates gendered messages of various types, such as WOMAN AS DEVIANT OTHER via the semantic derogation of women ${ }^{2}$ (cf. Schulz 1975) and MAN AS NORM via the generic use of the masculine (e.g., Hellinger and Bussmann 2001; Martyna 1983). The generic use of the masculine is what we turn to now.

In many Indo-European languages, the masculine gender is used for generic or indefinite reference, that is, for reference to female and male referents, or to referents whose sex is unknown, as shown in (5):

(5) $i$

fitités Jínun

eksetásis

DEF.M.NOM.PL student(M).NOM.PL take.3PL.PRS

$\operatorname{exam}(\mathrm{F}) \cdot \mathrm{ACC} . \mathrm{PL}$

'(Male) students take exams.'

Feminists criticize this practice for reflecting gender hierarchy at the social level and maintaining and enforcing men's dominance and women's subordination (cf. Hellinger and Bussmann 2001). The generic use of the masculine discloses the tacit and routine ways in which power works in discourse. It passes unremarkable by participants as part of our taken-for-granted knowledge about the world, it 'is there' when nothing special is happening, it is unnoticed and yet 'seen'. To illustrate this point, I examine one segment of talk-in-interaction (first analyzed in Alvanoudi 2014, pp. 100-1), using the tools of Conversation Analysis. Data analyzed in this paper stem from the Corpus of Spoken Greek (Institute of Modern Greek Studies).

\section{Excerpt 1}

1 Pol: Pos ta páte peðjá me ton je $\uparrow$ ró?=

'Guys how do you cope with the weather?'

2 Vas: =Ti na ta páme. na. eðó:, ímastan ap to

'So and so. here. we have been here since'

3 Savato[: $\left.{ }^{\circ} \mathrm{e}\right]$

'Saturday eh:'

4 Nat: -> [Apokli]zmée:ni, ]

2 Female-specific nouns tend to be associated with negative or pejorative meanings (e.g., spinster vs. bachelor). 
blocked.M.PART.NOM.PL

'Blocked.M,'

5 Vas: ->

'blocked.M, until'

6

tin detarti to vráði.<

'Wednesday night.' [apo]klizméni, >méxri

blocked.M.PART.NOM.PL until

In line 1, Polikseni initiates a new topic, asking her co-participants how they have been coping with the bad weather. She selects Vasilis and Natasa as next speakers via the address term peðjá ('guys'). Natasa and her husband, Vasilis, respond in the next lines in a collaborative manner (Lerner 2004). In lines 2 and 3, Vasilis deploys the first person plural verbs páme ('we go', meaning 'so and so') and imastan ('we were') to refer to a relational collectivity, i.e., a couple, that includes himself and his wife, Natasa. In line 4, Natasa continues the response that Vasilis started by using the masculine participle apoklizmé:ni ('blocked') to describe the collectivity. This response is brought to completion by Vasilis (lines 5-6) who repeats the masculine participle that Natasa used to describe the relational collectivity. In this segment, nothing special is happening with respect to participants' gender identities. Speakers get on with their usual business and use the male categorization of referents as a tool to achieve generic reference, that is, to refer to male plus female persons. Yet, their utterances routinely construct a web of gendered inferences. In using the masculine gender for generic reference, speakers tacitly presuppose the stereotypical association of man with the norm as an unquestioned assumption about the way in which the ordinary social world is organized. Male sex, which is morphologically codified, activates metonymically the category of human/universal, and guides speakers to interpret referents as not exclusively male (Alvanoudi 2014, pp. 56-58). That is, the concept of male sex serves as the vehicle through which the human/universal (target) is accessed and understood. If reference is successfully achieved, things get done and speakers move on with their daily business, why should the generic use of the masculine be a problem? Is a feminist approach to language use just another moment of being a feminist killjoy? The generic use of the masculine matters because it uncovers the tacit work of power structures and displays "patriarchal reasoning" that, in Ahmed (2017, p. 4) words, "goes all the way down, to the letter, to the bone." The heterosexual couple in this segment exists in the he that makes female difference invisible. As Ahmed (2017, p. 4) argues, words and worlds are not open to everyone: "He does not include she." In the next section, I discuss empirical data that provide evidence towards this direction.

\subsection{Language and Gender: Speakers' Cognition}

A number of studies within psycholinguistics and cognitive and social psychology (e.g., Braun et al. 2005; Gabriel and Gygax 2008; Gygax and Gabriel 2008; Irmen and Kurovskaja 2010; Irmen and Rossberg 2004; Stahlberg et al. 2007) provide ample empirical evidence for the correlation between the generic use of the masculine gender and speakers' strong tendency to interpret referents as male. More specifically, these studies report that masculine forms guide speakers to gender-specific rather than generic interpretations. For example, in a series of experiments Gygax and Gabriel (2008) asked French speakers to decide whether a person introduced by a kinship term, such as sister, could be part of a group represented by a role name, such as nurse or musicians. Participants were given role names in the masculine form or in the masculine or feminine form. Gygax and Gabriel (2008) found that regardless of role name stereotypicality, speakers had more difficulties in relating female kinship terms to role names in the masculine form. In other experiments, Gygax et al. (2008) presented French and German speakers with pairs of sentences: the first sentence introduced a role name which was stereotypically gender-specific or indefinite (e.g., The social workers were walking through the station), and the second sentence mentioned the gender of some of the members of the group (e.g., Since sunny weather was forecast several of the women weren't wearing a coat). Speakers had to decide whether the second sentence was a sensible continuation of the first one. Gygax et al. (2008) found that the 
proportion of positive and negative judgments depended on the grammatical gender of the role names deployed, that is, speakers tended to provide negative answers when role names were written in the masculine form and the second sentence represented women, independently of the stereotype portrayed by the role names. Overall, the generic use of the masculine is shown to increase the salience or visibility of men in discourse and make women invisible.

This finding is not surprising given the role of grammar in mediating speakers' cognition. Gender systems are grammatical categories that limit which aspects of experience speakers verbalize (Boas 1938, pp. 132-33), and guide speakers' thinking about the world at least at the time of speaking, that is, when speakers think for speaking (Slobin 1996). When speakers of a language with a sex-based gender system design and produce utterances, they choose to codify particular aspects of experience depending on what is grammaticized in the language they speak, that is, they codify referent's sex in an obligatory way. In this way, their thinking is attuned to the conceptual distinction of sex. Indications of the correlation between the masculine gender and the interpretation of referent(s) as male are also found in naturally occurring interaction (Alvanoudi 2014). This is what we turn to now.

Referent's gender is often displayed in the course of actions in conversation, without carrying any interactional relevance, as shown in Excerpt 1, and in the following exchange among three friends, Vaso, Yanna and Katerina (Alvanoudi 2014, pp. 95-97):

\section{Excerpt 2}

1

2 Vas: peðjá:, $=$

'Guys,'

3 Yan: =Borí na páo tin bémpti.

'I may go on Thursday.'

$4 \quad(0.7)$

5 Vas: $\quad$ de siko[nómaste ópos] ímaste, hh >na páme na

((in a laughing tone.

'why don't we stand up, hh and go to'

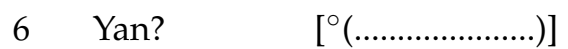

7 Vas: ðúme< ton árxoda ton ðaxtili[ ðjó: $\left.n_{i}\right]$

'see the Lord of the Rings $i$ '

8 Yan:

9

Vas:

…...................................................))

[Oa prépi]

'You should'

na çis klísi polí norítera isitíri[o.]

'have booked a ticket much earlier.'

[E] tóra,

'Eh now,'

éçi paরó:si moré. íne

'it became old you foolish. it' s been'

[ðjo vðomáðe:s.]

'two weeks.'

3 Kat: -> [eyó nóӨo polí kura]zméni peđjá apó

I feel.1SG.PRS very tired.F.PART.NOM.SG guys PREP

'Guys I feel very tired.F since'

${ }^{\circ} x$ ee:s. ðilaðí, $>$ ðe boró na páro ta póðjá $m u .^{\circ}<=$

'yesterday. that is, I cannot move my legs.' 
15 Vas: =xӨes ékatses méxri tis téseri:s?

'Yesterday did you stay until four?'

In lines 2, 5 and 7, Vaso suggests that they should go to the movies and Katerina rejects the suggestion in lines 13-15. She refers to herself via the personal pronoun eyó (' $\mathrm{I}$ ') and the first person singular verbs nó $\theta o$ ('I feel') and ðe boró na páro ('I cannot move'). The speaker uses the grammatically feminine participle kurazméni ('tired') to describe herself and give an account for her rejection. The gendered form makes the information of speaker's gender available in interaction as a covert assumption produced in routine ways when grammatical gender is used in individual self-reference. Yet, in this segment, Katerina uses the grammatically feminine form to implement a response rather than to invoke her feminine gender attributes.

On different occasions, gender can be advanced from "background to focal status" (Hopper and LeBaron 1998, p. 60) and become a relevant feature of the context, as in the following excerpt:

\section{Excerpt 3}

1 Ver: j†álo sizi>túsame, eména de máfises<

'we were talking about something else, you didn't let me'

2 na olokliróso ja tin americí pu í⿴囗e[la:. ]

'finish what I wanted to say about America.'

3 Pet:

[E áde] pes

'Eh come on you can talk'

4

ja tin americí, ce metá: $\theta a$ púme ja to internet.

'about America and then we will talk about the internet.'

5 Ver: E: óti tus éxo polí áxti:, (0.6) óti ðen dus:

'Eh [I want to say] that I despise them, (0.6) that I don't'

6

$\rightarrow$ siba日ó iðiétera tus amerikanú:s,

like.1SG.PRS particularly DEF.M.ACC.PL American(M).ACC.PL

'particularly like Americans,'

(0.6) e: >pistévo< óti íne mna xóra men

'(0.6) eh I believe that it is a country'

$8 \quad[\mathrm{me}$

9 Pet: $->$ [Tis amerikánes

texno个lojicí::, ]

'that has technological'

DEF.F.ACC.PL American(F).ACC.PL but

'But what about female Americans?'

10

(.)

11 Pet: [(Ci) ómos]

'And yet'

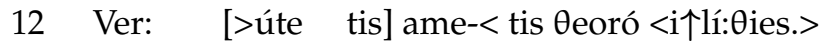

'I don't like female Ame- either I think they are stupid'

13 Pet: Ne. alá eména mu arésun.

'Yes. But I like them.'

14

In lines $5-8$, Vera delivers an argument and refers to Americans as a group via the noun phrase tus amerikanú:s ('the Americans'). This phrase is an initial non-recognitional form (Schegloff 1996) that consists of a masculine head noun and a masculine definite article. In line 9, Petros challenges Vera's claim via a question that distinguishes female Americans from male Americans. He repeats the initial non-recognitional form using the feminine gender (tis amerikánes) and, thus, attends to referents' 
feminine gender and brings heteronormativity to focused attention. Gender relevance is extended in the next turns and becomes a resource for subsequent talk. Vera claims that female Americans are stupid (line 12) and Petros claims that he likes them, displaying his heterosexual masculine identity (line 13). In this segment, Petros's use of the feminine form in line 9 makes gender interactionally relevant. How is this done? The masculine form in Vera's prior turn triggers a male sex-specific rather than a generic interpretation. Petros's next turn publicly displays this understanding (Sacks et al. 1974) by distinguishing female from male Americans and targeting female referents only. Thus, in this segment, we find indications of the cognitive role of grammatical gender by analyzing speakers' publicly observable behavior (see (Alvanoudi 2014) for more examples).

If grammar matters, how do feminists reclaim it? This question is addressed in the next section.

\section{Academic Feminism as Political Activism: The Rise of Undutiful Daughters}

Feminist linguists have been advocates of language reform since the 1970s. Women experience inequality in the way in which they are treated by language (Lakoff 1975) and find themselves silenced in a language shaped by a man-made worldview (Spender 1980). For this reason, language reform has been a key element in feminist political agendas. The non-sexist use of language is considered a tool for eliminating linguistic sexism and bringing about social change. Academic feminist initiatives on language reform deal with the following challenges.

(a) How can female difference be represented through language in positive ways? Reform practices target the semantic derogation of women and the generic use of the masculine (see (Nilsen 1977; Miller and Swift 1988; Kramarae and Treichler 1985; Frank and Treichler 1989) for reform proposals for English, (Tsokalidou 1996) for Greek, and (Pauwels 1998) for various languages, among other). With respect to the generic use of the masculine, two reform strategies have been proposed: feminization or gender-specification, that is, adding the feminine gender whenever the masculine gender is used for generic reference, and gender-neutralization, that is, avoiding denoting male or female sex and minimizing the linguistic expression of gender in relation to human referents (Pauwels 2003). For instance, instead of employing the masculine gender for generic reference (example 5), one can refer to both male and female students by using the feminine noun together with the masculine noun (example 6) or by de-gendering referents (example 7).

(6) $i$

fitités ce $i$ fitítries tu

DEF.M.NOM.PL student(M).NOM.PL and DEF.F.NOM.PL student(F).NOM.PL DEF.N.GEN.SG

prótu étus dínun eksetásis

first.N.GEN.SG year(N).GEN.SG take.3PL.PRS exam(F).ACC.PL

'First-year male and female students take exams.'

(7) to próto étos étos dini eksetásis

DEF.N.NOM.SG first.N.NOM.SG year(N).NOM.SG take.3SG.PRS exam(F).ACC.PL

'First-year students take exams.'

Although gender-specification provides a symmetrical representation of women and men, it is not linguistically viable given the structural properties of Greek (cf. Pavlidou 2006, p. 51). As mentioned in Section 3.1, a great number of linguistic items in Greek, such as nouns, adjectives, articles and participles, are inflected for grammatical gender in an obligatory manner. Moreover, the gender of the noun controls agreement with other elements in the noun phrase or the predicate. This means that the explicit marking of feminine and masculine gender of nouns and other elements in the clause is a non-economical practice, as speakers must repeat linguistic items in both genders when they speak or write. This strategy runs counter to the principle of Informativeness (Levinson 2000), according to which speakers should produce the minimal linguistic information sufficient to achieve their communicational ends and recipients should amplify the informational content of the speaker's utterance. The use of a default grammatical gender for generic reference is in line with this heuristic: the male sex activates the inference of human/universal and, thus, what is expressed 
simply is stereotypically exemplified. When speakers start using two grammatical genders instead of one, they deviate from the preference for minimization in communication, as shown in the following examples:

(8) ópços/ópça

fititís/fititria

$\theta e ́ l i$

whoever.M. $v O \mu /$ whoever.F.NOM student $(\mu)$.NOM.SG/student(F).NOM.SG

want.3SG.PRS na

ði to graptó tu/tis

SBJV see.3SG.PFV DEF.N.ACC.SG exam paper(N).ACC.SG his/her

'Every male and female student who wants to see his/her exam paper'

(9) $i$
fitités
ce $i$
fititries
ine

DEF.M.NOM.PL student(M).NOM.PL and DEF.F.NOM.PL student(F).NOM.PL COP.3PL.PRS

étimi ce étimes ja tis eksetásis

ready.M.NOM.PL and ready.F.NOM.PL for DEF.F.ACC.PL exam(F).ACC.PL

'Male and female students are ready for the exams.'

Instead of symmetrically marking gender, feminists can opt for an alternative strategy, that is, the generic use of the feminine gender (at least when most referents are female). This strategy exploits the preference for minimization and economy in communication and shifts the cultural pattern in invoking the metonymic inference 'female is human/universal'. When female sex serves as the vehicle through which all humans (target) are accessed and understood, women are construed as prototypical humans and empowered subjects. In the process of becoming women, feminization is 'strategic essentialism' (Spivak 1988) that challenges the patriarchal symbolic economy, which theorizes male as the One and the Same universal subject and female as the negative subordinate other (Irigaray 1985a). In reclaiming grammar, women represent female difference in positive ways, start to speak 'as women' and build a new feminine imaginary (Irigaray 1985b) in which categories have shifted ('woman' can stand for 'human') and new meanings are produced. A 'feminist' grammar prompts and sustains new habits of thinking about the world and the subjects we want to become (Braidotti 2002, cf. Section 1). New ways of speaking and thinking involve the positive affirmation of female difference as well as playing with the fuzzy boundaries of the male/female binary enforced by grammar. As Livia (2001, p. 192) observed, grammatical gender may act as a 'trap' that limits speakers to a static bipolar gender order but at the same time it can be used as a tool to express gender fluidity. One such case is found in the usage of grammatical gender by hijras in India (Hall and O'Donovan 1996). Hijras deploy the feminine and masculine grammatical gender in creative ways to construct a 'third gender' identity and transgress the female/male bipolarity. For example, they use the feminine gender in self-reference, whereas in referring to other hijras they switch between the feminine and the masculine gender depending on whether they want to express solidarity and social proximity or power and social distance.

(b) How do we break through to feminist futures? Given the role of language as a product of symbolic value exploited in late postmodern capitalism (cf. paradox 3), we need to ensure that feminist naming/labeling strategies will enhance women's differences as positive categories and that our hashtags do not end up on lipsticks and make-ups in the free market economy. Feminist academics can play an important role in this by implementing gender-fair language reforms and being in the vanguard of radical language planning and 'feminist linguistic activism' (Pauwels 2003). This encompasses processes of documenting sexist usages across different languages, developing proposals of change in different national contexts, implementing the changes in cooperation with educational and legislative authorities and the media, and assessing the success of language planning (Pauwels 2003). I argue that language reform and the re-appropriation of meanings is an essential part of feminist academic activism. Feminist academics are telling stories of feminist futures. In telling these stories, we speak as women and create cartographies of our different locations, and, for this reason, we need a 'feminist' grammar that can express female sexual difference and differences within the category of woman. How can gendered forms that presuppose and enforce gender binaries become signifiers of multiplicity and difference? Who are the women found in she? The answer to this question is political. An inclusive she 
presupposes multiplicity among the users of feminine forms, that is, among the undutiful daughters who implement language and social reform strategies. A feminist movement, that engages women of different locations in terms of age, class, race, ethnicity and sexual orientation, can give rise to multiple voices and generate concepts in which the prototypical woman is not necessarily white or heterosexual.

The arguments presented in this section are related to paradox 1 and the question of agency in corporate academia. How can Third Millennium feminist academics become agents of social reform? How do we deal with the tension between the negative ways in which we experience academic labor and the role of labor as an active force of affirmation? On the one hand, Gill (2010, p. 229) describes labor in neoliberal university as participation in a culture of exhaustion, stress, aggression, shame and guilt related to precarious jobs and a 24/7 workload. On the other hand, Hardt and Negri (2003, p. 6) argue that living labor is "the internal force that constantly poses not only the subversion of the capitalist process of production but also the construction of an alternative." I propose that identifying ways in which feminist knowledge produced in academia can effect social change is one strategy of resistance that can transform our labor into a force of subversion and enable us to rethink our locations in terms of power as potentia (cf. Section 1).

\section{Conclusions}

To sum up, this paper makes an argument about feminist politics in academia. The analysis of gendering linguistic practices in Greek shows that language constructs gender on the basis of social asymmetry and guides speakers to biased conceptualizations of gender. It is argued that 'old debates' about feminist language reform have become prominent sites of political struggle in postmodern capitalism and feminist academic activism. Feminist politics can take place in corporate academia in the Third Millennium, when walls are dismantled from within.

Funding: This research received no external funding.

Conflicts of Interest: The author declares no conflict of interest.

\section{Abbreviations}

$\begin{array}{ll}1 & \text { first person } \\ 2 & \text { second person } \\ 3 & \text { third person } \\ \text { ACC } & \text { accusative } \\ \text { COP } & \text { copula } \\ \text { DEF } & \text { definite } \\ \text { F } & \text { feminine } \\ \text { GEN } & \text { genitive } \\ \text { M } & \text { masculine } \\ \text { N } & \text { neuter } \\ \text { NOM } & \text { nominative } \\ \text { P } \alpha \text { RT } & \text { participle } \\ \text { PFV } & \text { perfective } \\ \text { PL } & \text { plural } \\ \text { PRS } & \text { present } \\ \text { PREP } & \text { preposition } \\ \text { SG } & \text { singular } \\ \text { SBJV } & \text { subjunctive }\end{array}$

\section{References}

Ahmed, Sara. 2017. Living a Feminist Life. Durham: Duke University Press.

Aikhenvald, Alexandra Y. 2000. Classifiers: A Typology of Noun Categorization Devices. Oxford: Oxford University Press. 
Alvanoudi, Angeliki. 2009. Teaching gender in the neoliberal university. In Teaching with the Third Wave-New Feminists' Explorations of Teaching and Institutional Contexts. Edited by Daniela Gronold, Brigitte Hipfl and Linda Lund Pedersen. Stockholm: ATHENA3 Advanced Thematic Network in Women's Studies in Europe, University of Utrecht and Centre for Gender Studies, Stockholm University Press, pp. 37-50.

Alvanoudi, Angeliki. 2014. Grammatical Gender in Interaction: Cultural and Cognitive Aspects. Leiden: Brill.

Boas, Franz. 1938. Language. In General Anthropology. Edited by Franz Boas. Boston. New York: D.C. Heath and Company, pp. 124-45.

Braidotti, Rosi. 1991. Patterns of Dissonance: A Study of Women in Contemporary Philosophy. Oxford: Polity.

Braidotti, Rosi. 2002. Metamorphoses: Towards a Materialist Theory of Becoming. Cambridge: Polity.

Braun, Friederike, Sabine Sczesny, and Dagmar Stahlberg. 2005. Cognitive effects of masculine generics in German: An overview of empirical findings. Communications 30: 1-21. [CrossRef]

Cameron, Deborah. 2005. Verbal Hygiene. London: Routledge. First published 1995.

Enfield, Nick J. 2013. Relationship Thinking: Agency, Enchrony, and Human Sociality. New York: Oxford University Press.

Fairclough, Norman. 2003. 'Political correctness': The politics of culture and language. Discourse E Society 14: $17-28$.

Frank, Francine W., and Paula A. Treichler. 1989. Language, Gender, and Professional Writing: Theoretical Approaches and Guidelines for Non-Sexist Usage. New York: Modern Language Association.

Gabriel, Ute, and Pascal Gygax. 2008. Can language amendments change gender representation? The case of Norway. Scandinavian Journal of Psychology 49: 451-57. [CrossRef] [PubMed]

Gill, Rosalind. 2010. Breaking the silence: The hidden injuries of the neoliberal university. In Secrecy and Silence in the Research Process: Feminist Reflections. Edited by Roisin Ryan-Flood and Rosalind Gill. Abingdon: Routledge, pp. 228-44.

Gygax, Pascal, and Ute Gabriel. 2008. Can a group of musicians be composed of women? Generic interpretation of French masculine role names in absence and presence of feminine forms. Swiss Journal of Psychology 67: 143-51. [CrossRef]

Gygax, Pascal, Ute Gabriel, Oriane Sarrasin, Jane Oakhill, and Alan Garnham. 2008. Generically intended, but specifically interpreted: When beauticians, musicians, and mechanics are all men. Language and Cognitive Processes 23: 464-85. [CrossRef]

Hall, Kira, and Veronica O'Donovan. 1996. Shifting gender positions among Hindispeaking hijras. In Rethinking Language and Gender Research: Theory and Practice. Edited by Victoria L. Bergvall, Janet M. Bing and Alice F. Freed. London: Longman, pp. 228-66.

Hardt, Michael, and Antonio Negri. 2003. Labor of Dionysus: A Critique of the State-Form. Minneapolis: University of Minnesota Press.

Hellinger, Marlis, and Hadumod Bussmann. 2001. Gender across languages: The linguistic representation of women and men. In Gender across Languages: The Linguistic Representation of Women and Men. Edited by Marlis Hellinger and Hadumod Bussmann. Amsterdam: John Benjamins, pp. 1-25.

Hellinger, Marlis, and Hadumod Bussmann, eds. 2001-2003. Gender across Languages: The Linguistic Representation of Women and Men. Amsterdam: John Benjamins.

Hopper, Robert, and Curtis LeBaron. 1998. How gender creeps into talk. Research on Language and Social Interaction 31: 59-74. [CrossRef]

Hymes, Dell H. 1964. Language in Culture and Society: A Reader in Linguistics and Anthropology. New York: Harper \& Row.

Irigaray, Luce. 1985a. The Speculum of the Other Woman. Ithaca: Cornell University Press.

Irigaray, Luce. 1985b. This Sex Which is Not One. Ithaca: Cornell University Press.

Irmen, Lisa, and Julia Kurovskaja. 2010. On the semantic content of grammatical gender and its impact on the representation of human referents. Experimental Psychology 57: 367-75. [CrossRef] [PubMed]

Irmen, Lisa, and Nadja Rossberg. 2004. Gender markedness of language: The impact of grammatical and nonlinguistic information on the mental representation of person information. Journal of Language and Social Psychology 23: 272-307. [CrossRef]

Kramarae, Cheris, and Paula A. Treichler. 1985. A Feminist Dictionary. London: Pandora Press.

Lakoff, Robin. 1975. Language and Woman's Place. New York: Harper and Row. 
Lerner, Gene H. 2004. Collaborative turn sequences. In Conversation Analysis: Studies from the First Generation. Edited by Gene H. Lerner. Amsterdam: John Benjamins, pp. 225-56.

Levinson, Stephen C. 2000. Presumptive Meanings: The Theory of Generalized Conversational Implicature. Cambridge: MIT Press.

Livia, Anna. 2001. Pronoun Envy: Literary Uses of Linguistic Gender. Oxford: Oxford University Press.

Martyna, Wendy. 1983. Beyond the he/man approach: The case for nonsexist language. In Language, Gender and Society. Edited by Barrie Thorne, Cheris Kramarae and Nancy Henley. Rowley: Newbury House, pp. 25-37.

Mason, Paul. 2015. Postcapitalism: A Guide to Our Future. London: Allen Lane.

Miller, Casey, and Kate Swift. 1988. The Handbook of Non-Sexist Writing for Writers, Editors and Speakers. London: The Women's Press. First published 1981.

Mohanty, Chandra T. 2003. Feminism without Borders: Decolonizing Theory, Practicing Solidarity. Durham: Duke University Press.

Negri, Toni. 1989. The Politics of Subversion: A Manifesto for the 21st Century. Cambridge: Polity Press.

Nilsen, Alleen P. 1977. Sexism as shown through the English vocabulary. In Sexism and Language. Edited by Alleen P. Nilsen, Haig Bosmajian, H. Lee Gershuny and Julia P. Stanley. Urbana: National Council of Teachers of English, pp. 27-41.

Ochs, Elinor. 1992. Indexing gender. In Rethinking Context: Language as an Interactive Phenomenon. Edited by Alessandro Duranti and Charles Goodwin. Cambridge: Cambridge University Press, pp. 335-58.

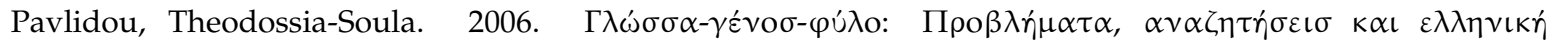
$\gamma \lambda \omega \sigma \sigma \alpha$ [Language-grammatical gender-social gender: Problems, queries and the Greek language]. In $\Gamma \lambda \omega ́ \sigma \sigma \alpha-\Gamma \varepsilon ́ v o \sigma-\Phi u ́ \lambda o$. [Language-Grammatical Gender-Social Gender]. Edited by Theodossia-Soula Pavlidou. Thessaloniki: Institute of Modern Greek Studies, pp. 15-64.

Pauwels, Anne. 1998. Women Changing Language. London: Addison Wesley Longman.

Pauwels, Anne. 2003. Linguistic sexism and feminist linguistic activism. In The Handbook of Language and Gender. Edited by Janet Holmes and Miriam Meyerhoff. Oxford: Blackwell Publishing, pp. 550-70.

Pereira, Maria do Mar. 2016. Struggling within and beyond the performative university: Articulating activism and work in an "academia without walls". Women's Studies International Forum 54: 100-10. [CrossRef]

Sacks, Harvey, Emanuel A. Schegloff, and Gail Jefferson. 1974. A simplest systematics for the organization of turn-taking for conversation. Language 50: 696-735. [CrossRef]

Schegloff, Emanuel A. 1996. Some practices for referring to persons in talk-in-interaction: A partial sketch of a systematics. In Studies in Anaphora. Edited by Barbara A. Fox. Amsterdam: John Benjamins, pp. 437-85.

Schulz, Muriel R. 1975. The semantic derogation of woman. In Language and Sex: Difference and Dominance. Edited by Barrie Thorne and Nancy Henley. Rowley: Newbury House, pp. 64-75.

Slobin, Dan Isaac. 1996. From "thought and language" to "thinking for speaking". In Rethinking Linguistic Relativity. Edited by John J. Gumperz and Stephen C. Levinson. Cambridge: Cambridge University Press, pp. 70-96. Spender, Dale. 1980. Man Made Language. London: Routledge and Kegan Paul.

Spivak, Gayatri C. 1988. Can the subaltern speak? In Marxism and the Interpretation of Culture. Edited by Cary Nelson and Lawrence Grossberg. Urbana: University of Illinois Press, pp. 271-315.

Stahlberg, Dagmar, Friederike Braun, Lisa Irmen, and Sabine Sczesny. 2007. Representation of the sexes in language. In Social Communication. Edited by Klaus Fiedler. New York: Psychology Press, pp. 163-87.

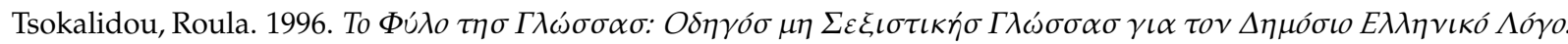
[The Gender of Language: A Guide to Non-Sexist Language for Public Greek Speech]. Athens: Syndesmos Ellinidon Epistimonon.

Washington Post Staff. 2015. Full text: Donald Trump announces a presidential bid. Washington Post Staff. June 16. Available online: https://www.washingtonpost.com/news/post-politics/wp/2015/06/16/full-textdonald-trump-announces-a-presidential-bid/?noredirect=on\&utm_term=.ad9c079cddbb (accessed on 1 June 2018).

Woolf, Virginia. 2002. A Room of One's Own. London: Penguin Books. First published 1928.

(C) 2018 by the author. Licensee MDPI, Basel, Switzerland. This article is an open access article distributed under the terms and conditions of the Creative Commons Attribution (CC BY) license (http:// creativecommons.org/licenses/by/4.0/). 